\title{
DETERMINING THE EFFECT OF KNOWLEDGE SHARING, TEAMWORKING AND TRANSFORMATIONAL LEADERSHIP ON ORGANIZATIONAL CITIZENSHIP BEHAVIORS IN INFORMATION SOCIETY
}

\author{
*Abdülkadir AKTURAN \\ *Hülya GÜNDÜZ ÇEKMECELİĞLU \\ **Ali ACARAY \\ ${ }^{*}$ Kocaeli University, Turkey \\ ${ }^{* * *}$ Recep Tayyip Erdoğan University, Turkey
}

\begin{abstract}
In the last two decades a substantial amount of research has focused on the concept of organizational citizenship behavior. Sharing the needed knowledge in organizations empower all of the employee. In particular, while performing team work, the applied leadership style and the possibility of access to knowledge of employee, brings more power to the organizations. The purpose of our study is to determine the effect of information sharing, teamworking and transformational leadership on organizational citizenship behaviors in information society. The survey of this study is conducted on 300 personnel of an educational institution which serves in many cities in Turkey. The obtained data from the questionnaires are analyzed through the SPSS statistical packaged software.
\end{abstract}

Keywords: Information Sharing, Teamworking, Ttransformational Leadership , Organizational Citizenship Behaviors.

\section{INTRODUCTION}

Our world and its economy has become global. Today’s economy presents challenging opportunities as well as dramatic uncertainty. The new economy has become knowledge based and is performance driven. Managers in organizations become different new responsibilities to do their task. Management's primary job is to make organizations operate effectively. Society's work gets done through organizations and management's function is to get organizations to perform that work. Getting organizations to operate effectively is difficult, however. Understanding one individual's behavior is challenging in and of itself; under standing group that's made up of different individuals and comprehending the many relationships among those individuals is even more complex (Nadler et.al.,1982:35). In our global world, knowledge has become more important with each passing day. As we see a global definition of knowledge society as "An knowledge society is a society where the creation, distribution, use, integration and manipulation of knowledge is a significant economic, political, and cultural activity" the use of the concept knowledge society had already become widespread. According to the studies and theories, the transition to the knowledge society is characterised by a number of changes in production and consumption. The key argument is that production of knowledge is becoming more importance relative to other forms of production and that employment is shifting towards knowledge-related activities (Skogerbø, E., Syvertsen T., 2004:46). To be competitive in today's business life, knowledge must be used professionally and effectively by all employee. Knowledge, which has become the most powerful tool for all organizations, produces more value when it is shared. Sharing the necessary knowledge in organizations empower all of the employee. In particular, while performing team work, the applied leadership style and the possibility of access to knowledge of employee, brings more power to the organizations. Knowledge sharing in teamwork allows competitive advantage in today's business life. There has been significant debate as to the styles and characteristics of leadership that causes ideal team performance (Sohmen V. S. ,2013:1). We can not imagine leadership and teamwork existing without each other. Nowadays in the knowledge-intensive world of business, leaders influence and motivate teams. 
In the last two decades a substantial amount of research has focused on the concept of organizational citizenship behavior. The widespread interest in organizational citizenship behaviors stems from the belief that these behaviors enhance individual, unit and organizational performance by making organizations more attractive places to work for one's coworkers (Organ, 1988; Netemeyer et al., 1997; Organ, 1988; Podsakoff et al.,1996; Podsokoff, Mac Kenzie, 1997). Since the development of the concept, much research has been focused to explore the antecedents of OCBs. The most researh on OCB has related to individual antecedents of OCB- including personality, satisfaction (Bateman, Organ, 1983, Organ, Lingl, 1995), commitment (O’Reilly \& Chatman, 1986), perceptions of fairness (Moorman, Niehoff, Organ, 1993), intrinsic and extrinsic job attitudes (Williams \& Anderson, 1991), job status, identification work value (Feather, Rauter, 2004), justice (Nadiri, Tanova, 2010). Some research on OCB has focused on context related variables. For examble researchers have suggested important relationship between OCB and task characteristics (Podsakoff \& McKenzei, 1995), organizational politics, organizational support (Randall, et all, 1999), social support (Chu, Lee, Hsu, 2006), leader behaviors (Padsokoff, et al., 1990, Truckenbrodt, 2000) abusive supervision (Zellars, et al, 2002), organizational learning (Somech, Drach-Zahavy, 2004), work values (Feather, Rauter, 2004). However, the relatioship among team work, knowledge share, and organizational citizenship behaviors are not examined enough. However, in order for the employee to demonstrate organizational citizenship behavior, it seems necessary to build a culture of communication, trust, team workking, participation and knowledge sharing. Thus, the purpose of this research is to examine and compare the effects of team work, knowledge share and participative management on five dimensions of organizational citizenship behaviors.

\section{LITERATURE REVIEW AND HYPOTHESES}

The development of Knowledge - communication technologies, and the effects of globalization, has led to an inevitable transformation in institutional and social dimensions. This transformation is considered as "informatics revolution" or "knowledge society" today (Yıldırım U., Öner Ş., 2004:1). In order to achieve superiority over the competition businesses want to keep Knowledge in their hands and to take advantage of as much of the knowledge technology in Knowledge society (Selvi Ö., 2012:1).

Knowledge society has occurred as a step with an increasing use of knowledge technology in developed countries such as Western Europe, Japan and America in 1950 - 1960s. The most important feature of this phase shaped in developed countries is using knowledge and knowledge technology in all areas. Therefore, the developments of knowledge society leads to increase productivity in production and encourags new technological, economic, social and cultural development in a short time (Selvi Ö., 2012:192). There are many definitions for Knowledge Society:

- Knowledge society is a society, that provide access to the Technologies and use these technologies through new knowledge and communication Technologies.

- A society that organises itself around knowledge in the interest of social control, and the management of innovation and change (Daniel Bell).

- A society where knowledge is used as an economic resource, the community harnesses/exploitsit, and behind it all an industry develops which produces the necessary knowledge (Nick Moore)

- A new type of society in which humanity has the opportunity to lead a new way of life, to have a higher standard of living, accomplish better work, and to play a better role in society thanks to the global use of knowledge and telecommunication technologies.” (Béla Murányi).

With another approach, in the knowledge society knowledge has been turned into capital, raw materials, energy and manpower such as the factors of production, used as raw materials and product in the economy, shared by everyone and accepted as a cultural value in society. Knowledge society is the structure of society which is started to be used in all areas of knowledge and communication Technologies (Rukanc1 ve Anameriç, 2004).

\section{Knowledge sharing}

Knowledge has been commonly known as the major source for creating an organization's sustainable competitive advantage (Fang, Y.,et al.,2010:42). Collins and Hitt (2006:148) illustrated in their study that knowledge sharing is an accumulation of social capital for an organization as if there is an adequate social capital is available then the knowledge possessed by an individual can be shared efficiently and effectively in 
the organization. Nevertheless the willingness of the members to share their knowledge with other members based on the organizational structure and social relations in the organization ( Islam T. et al., 2012:795). The importance of organizational knowledge has supported several knowledge management activities that are intended to realize knowledge creation, retention and distribution (Bock, G.W., et al.,2010:99). In fact, the knowledge of human resources, customers, innovations and processes consist of managerial intellectual capital that will be incorporated into decisions (Shang, S.S.C., et al.,2009:99). However, the transition of knowledge across individuals and organizational boundaries, and into organizational practices relies heavily on individual employees' knowledge sharing behavior (Bock, G.W., et al., 2005:101). When individuals are psychologically attached and identified with an organization, they trust and interact with other organizational members and make it easy and comfortable to share knowledge with them ( Islam T. Et al., 2012:795). Social factors are more deterministic than extrinsic benefits in knowledge -sharing behaviors (Bock, G.et al., 2005:99)

Knowledge sharing potentially carries the meaning, to share sensitive knowledge about costs, productivity, financial and performance with employees of the organization's (Scott ve diğ., 2004:333). With knowledge sharing, managers strengthen teams that can take their own decisions. This dimension creates a situation for workers to understand the meaning of their work, to feel being of competence in fulfilling the business and have an impact in the direction of the organization where they feel themselves better (Bandura, 1982:122). In other words, knowledge sharing constitues the basis of empowerment. The sharing of sensitive and important knowledge will allow employees to understand the duties and responsibilities, organization and the top management's judgments and behaviors. Trust, mutual understanding and communication resulting from this undestanding will give a potential ability to employee to govern themselves (Si ve Wei, 2012: 303). As seen, in companies to obtain the knowledge, sharing among employees, development and management emerges as a strategic activity. (Demirel,2008:199).

Knowledge sharing is one of the most critical point for knowledge society. Without knowledge sharing, it is not possible to see an efficient knowledge society. Bureaucratic structure of the organization, limits the sharing of knowledge particularly sensitive and important knowledge. Knowledge sharing, why it is the most important first step can be summarized as follows (Randolph, 1995: 22):

- Without knowledge, it is not possible to wait from the employees to act responsibly for the organization and to make a difference in their movements.

- Knowledge sharing significantly increases the level of confidence in the organization.

- In particular, the sharing of sensitive knowledge, cause employees to embrace the work.

To obtain the innovative competitive advantage in favor of the organizations effectively, organizations provide substantial knowledge to employees, employees to other employees (Taş, 2011:120). After providing knowledge sharing, and the foundation of trust the next step will be the creating autonomy structure based working teams (Randolph, 1995: 23-25). Therefore, the following hypothesis is proposed:

Hypothesis 1: Knowledge sharing has a positive relationship with attitude toward Organizational Citizenship Behaviors.

\section{Team Working}

Today, many organizations are formed self-governing teams, and be given responsibility over the whole of a product or process in such teams. (Akçakaya, M., 2010:158). Nowadays, in many organizations, complex decisions are taken, and in this context the decision-making of a single employee does not provide efficiency. In other words, it can be said that a group of employees provide input to the complex decision-makings. Teams with the structure of creating synergy, create significant knowledge and also serve as a mechanism to provide support to the empowered personnel (Randolph, 1995: 27).

Scarnati defined Teamwork (2001:5) "as a cooperative process that allows ordinary people to achieve extraordinary results". Teamwork is a very essential part of workplace success. When employees work together to accomplish a goal, everyone benefits. Teamwork allow individuals working together in a cooperative environment to achieve planned team goals through sharing knowledge and skills. (Tarricone P. \& Luca J.,2002:641) There are many definitons about team working. As a result we can make a common definition about team work; "Teams are groups of people with complementary skills who are committed to a 


\section{Journal of Global Strategic Management | V. 9 | N. 1 | 2015-June | isma.info | 75-86 | DOI: 10.20460/JGSM.2015915630}

common purpose and hold themselves mutually accountable for its achievement. Ideally, they develop a distinct identity and work together in a co-ordinated and mutually supportive way to fulfil their goal or purpose" (www.constructingexcellence.org.uk. 2004:5).

Team responsibility and working, provide the opportunity of decision-making tool position. In this process, in fact, efforts are made teams to take the the position of the hierarchy. So, it is necessary to increase the responsibility of the team with the hierarchy reduction and new arrangements and structures within the organization. However, many managers act for fear of losing the power control at this point and can show resistance to empowerment. When team take place of the hierarchy, roles of managers will be; coaching, consulting and leadership etc. as varies. Giving more responsibility to the team should be supported by new training programs. This is meant to be less controlling of the first supervisor than before, incentives for change and support should be provided by management. This also requires the adoption of certain risks and fear. (Si ve Wei, 2012: 304). This dimension; works in a wide range of team training, and covers some of the responsibility for work outcomes. This dimension essentially aims to strengthen the effects of the qualification of the employees in the organization (Scott, E. S. ve diğ., 2004:336).What to do in order to replace the position of the hierarchy with teams is as follows: (Randolph, 1995: 29):

- Continuing education,

- Work on the leadership gap,

- To accept the fear.

When the team's responsibility increased, as the basis for implementation, decision-making expected in terms of the team members and to act so, training is very important.

The disappearance of the hierarchy creates a leadership gap. Initially, the teams need to have strong leaders, leadership, encouragement, and support.

Kelchner (2013) points out that maximizing the diversity within a team is important to allow for different skill-sets to come together and to share ideas for the best solution possible.Successful teams are characterised by a team spirit based around trust, mutual respect, helpfulness and - at best - friendliness (www.constructingexcellence.org.uk. 2004:5). Simply bringing people together does not necessarily ensure they will function effectively as a team or make appropriate decisions. Teams are composed of people who have a variety of emotional and social needs which the team can either frustrate or help to meet. Teams have several characteristics: diverse individuals, a common goal, a sense of community, knowledgesharing, and, concerted effort (Sohmen V.S., 2013:4). Indeed, strong leaders build strong teams: groups of people who work together in cooperative, goal-oriented effort. In the knowledge-intensive world of today, leaders influence and motivate teams. They do not coerce. They achieve results by developing a shared vision and communicating it to the team whilst influencing with passion. If we suppress the natural dynamic flow of a team-with possible conflicts-self-induced barriers are created within that team. Therefore, the leader should strive to understand the culture of each team and find ways to strengthen the natural dynamics of that team and each of its members. A creative approach needs to be taken to drive the strategic vision of the organization through effective leadership (Sohmen V.S., 2013:4). Therefore, the following hypothesis is proposed:

Hypothesis 2: Team working has a positive relationship with attitude toward Organizational Citizenship Behaviors.

\section{Transformational Leadership}

Leadership is critical to teamwork. The team leader is the person responsible for ensuring that members work effectively together to achieve their goal or objective and must facilitate the co-operation necessary for the team to perform well. The leader must also ensure that the team has the resources and knowledge necessary to complete its task. The leader should be a role model for the team - good at communicating openly and honestly and winning the respect and trust of all involved. Creating opportunities for team members to participate and contribute to the task constructs a sense of common ownership of both the problem and its solution. Considering the "five-dimensional leadership competence model" (Transformational; Transactional; Organic; Contemporary; and, Ethical) (Cameron \& Whetten, 2011), we will handle with “ Transformational Ledaership” in this study. Sohmen V.S. (2013:6).,describes Transformational Leaders as 
Journal of Global Strategic Management | V. 9 | N. 1 | 2015-June | isma.info | 75-86 | DOI: 10.20460/JGSM.2015915630

"Transformational leaders are charismatic individuals who have the ability to influence a team to meet the organization's strategic goals. These leaders encourage and enable the development of an organization that is characterized by a culture based on integrity, transparency, and genuine respect for others” . The transformational leader leads by inspiring and stimulating followers and by creating highly absorbing and motivating visions (Bass, Waldman, Avolio, \& Bebb, 1987:75). Transformational leaders develop a vision and motivate their followers to strive for this vision. Transformational leadership make the audiences, about their motivation to do more than initially expected (Bolat and Seymen, 2003: 64). Based on this article, the following hypothesis is developed:

Hypothesis 3: Transformational Leadership has a positive relationship with attitude toward Organizational Citizenship Behaviors.

\section{Organizational Citizenship Behaviors}

Derived from Katz's (1964) category of extra role behavior (Schappe 1988, 277) OCB has been defined as individual behavior that is discretionary, not directly or explicitly recognized by the formal reward system and that in the aggregate promotes the effective functioning of the organization. Discretionary, means that the behavior is not an enforceable requirement of the role or the job description, that is the clearly specifiable terms of the person's employment contract with the organization; the behavior is rather a matter of personal choice, such that its omission is not generally understood as punishable (Organ (1988, p.4). Examples of OCBs include helping coworkers with work related problems, not complaining about trivial problems, behaving courtesely to coworkers, and speaking approvingly about the organization to outsiders. A key component of the OCB definition is that omission of the OCBs is not punishible (Zellars, Tepper, Duffy, 2002: 1068).

Although there is no clear consensus with the literature on the number of dimensions of OCBs, Organ (1988) and other studies (Padsakoff \& MacKenzei, 1994; Padsakoff et al, 1997; Farth, Zhong, \& Organ, 2004) have proposed a variety of forms, including altruism, courtesy, sportsmanship, civic virtue, and conscientiousness. Altruism is discretionary behavior that has the effect of helping a specific other person with an organizationally relevant task. Courtesy is is discretionary behavior aimed at preventing work-related problems with others (e.g., touching base with the manufacturing plant before making a large sale final). Sportmanship is behavior that tolerating in good spirit the occasional hardships and deprivations that unpredictably befall individuals in the course of organizational endeavors (Organ 1988a, p. 11). Civic virtue is behavior indicating that the employee responsibly participates in, and is concerned about, the life of the company. Finally, conscientiousness is discretionary behavior that goes well beyond the minimum role requirements of the organization (MacKenzie, Podsakoff and Fetter 1993). Although OCB is discretionary behavior researchs pointed out that today "the ideal worker is an employee who not only demonstrates high levels of task performance, but also engages in high levels of OCB as well (Bolino and Turnley, 2005, p. 740).

There are some possible causes why helping behaviors might be positively related to work group or organizational effectiveness. For example, OCBs (1) provide a means of managing the inter-dependencies among members of a work unit, which increases the collective outcomes achieved; (2) reduce the need for an organization to devote scarce resources to simple maintenance functions, which frees up resources for productivity; and (3) improve the ability of others (i.e., coworkers and managers) to perform their jobs by freeing up time for more efficient planning, scheduling, problem solving, and (4) enable the organization to more effectively adapt to environmental changes and (5) strengthening the organization's ability to attract and retain the best employees. Overall, OCB enhances the social and psychological work environment in such a way that it supports task proficiency and can increase group performance (Organ, 1988; Netemeyer, 1997, 86), Podsakoff \& MacKenzie, 1994; 1997). OCBs create efficiencies by reducing the need for monitoring and freeing time for more valuable management activities such as scheduling and problem solving (Podsakoff et al., 1995).

OCB develops through the voluntary efforts of employees to exceed prescribed instructions and tasks. These efforts are oriented towards two major targets, with members of the organization being the first target. In this case, OCB is revealed as helping (forms of behaviour reflecting social, moral or practical assistance). Helping may reflect significanttraits such as altruism, conciliation and even courtesy. Giving and receiving 
help strengthens ties between employees. Helping promotes the desire to reciprocate, contributes to learning the ropes and frees management control over tasks, allowing management to concentrate on developing goals, etc. (Paille, Grima, 2011, p.4).

\section{Relationship Between knowledge sharing, team working, transformational leadership and $O C B$}

Bolino, M.C., et al., (2002:510) mentioned in their study that that OCBs play a very vital role in the development of social capital in organizations. Their conceptual framework indicates that OCBs include loyalty, obedience and participation, all of which contribute to the creation of the structural, relational and cognitive aspects of social capital. OCB's enhanced when employee's perceived that there is a supportive culture in their organizations. By social exchange theory it is also mentioned that when employees perceive that their organization supports them they show citizenship behaviors (Islam T. et al., 2012:796). Knowledge sharing behavior is regarded as the degree to which employees share their acquired knowledge with their colleagues (Ryu S., Ho S.H., and Han I.,2003:119). Inherently, the transfer of knowledge from one individual or one unit of an organization to another significantly contributes to the organizational performance (Argote, L., et al., 2000:7). Facilitating knowledge sharing is a complicated task, as one of the major challenges concern is the willingness of organizational members to share their knowledge with other co-workers(Lam, A., and Lambermont-Ford, J.P., 2010:57). In the workplace, knowledge sharing behavior is viewed as voluntary and is represented by OCB, and another social psychological factor, namely, sense of self-worth. Ipe (2003) indicates that many researchers have handled the motivation for knowledge sharing as a function of reciprocity. And the organizational climate must be ready for knowledge sharing. Employee development through team building and employment of self-managed teams has been found to be positively related to improved organizational productivity (Druskat and Wolf 1999). Effective teams are teams who can achieve high standards of task performance, and reach high levels of satisfaction for their members. Leadership behaviour, among other factors, no doubt influences employees' attitude to work, and team leadership style is one of the major factors that effects team's success. A study by O'Connor (1972) revealed that companies earned higher net profits with effective leaders. It therefore holds that successful organizational citizenship behaviour is highly dependent on effective leadership.

\section{METHODOLOGY}

\section{Research Objective}

The purpose of this survey is to identify the effect of $f$ information sharing, teamworking and transformational leadership on organizational citizenship behaviors in information society. To test the propositions, a field survey using questionnaires were conducted.

\section{Sampling and Data Collection}

The main body of this survey comprises an educational institute operating in Turkey. This institute is operating since a long time in the education sector throughout Turkey, and was carried out in a wellestablished company operating in many cities and towns in Turkey. The survey of this study is conducted on 300 personnel of this institution. Despite these fundamental constraints of the study should be evaluated in the literature as well as contributed to a number of practitioners. Data obtained from those 300 questionnaires were analyzed through the SPSS statistical packet program.

\section{Measures}

The scale items for attitude toward knowledge sharing and team working are adapted from Blanchard et.al. (1995). In order to measure leadership issue, "Multifactor Leadership Questionnaire" were used developed by Bass and Avolio (1995). The scale developed by Padsakoff et al. (1990) is used to measure the organizational citizenship behavior. Organizational citizenship behavior is measured as 24 variables in five dimensions; conscientiousness, civic virtue, sportsmanship, altruism and courtesy.

All of the variables in the research model was measured using 5-point Likert scale. A six-point scale is used, with anchors ranging from 1="extremely disagreed", 2="“disagreed”, 3="somewhat disagreed/somewhat agreed”, 4=“agreed”, to 5=“extremely agreed”. 
The main and sub-hypotheses based on the measurement model study was as follows.

H1: Knowledge Sharing has a positive effect on organizational citizenship behavior.

- H1a1 Knowledge sharing affects conscientiousness dimension by $\propto=0.05$ significance level.

- H1a2 Knowledge sharing affects sportmanship dimension by $\propto=0.05$ significance level.

- H1a3 Knowledge sharing affects courtesy dimension by $\propto=0.05$ significance level.

- H1a4 Knowledge sharing affects civic virtue dimension by $\propto=0.05$ significance level.

- H1a5 Knowledge sharing affects altruism dimension by $\propto=0.05$ significance level.

H2: Teamworking has a positive effect on organizational citizenship behavior.

- H2a1 Teamworking affects conscientiousness dimension by $\propto=0.05$ significance level.

- H2a2 Teamworking affects sportmanship dimension by $\propto=0.05$ significance level.

- H2a3 Teamworking affects courtesy dimension by $\propto=0.05$ significance level.

- H2a4 Teamworking affects civic virtue dimension by $\propto=0.05$ significance level.

- H2a5 Teamworking affects altruism dimension by $\propto=0.05$ significance level.

H3: Transformational Leadership has a positive effect on organizational citizenship behavior.

- H3a1 Transformational Leadership affects conscientiousness dimension by $\propto=0.05$ significance level.

- H3a2 Transformational Leadership affects sportmanship dimension by $\propto=0.05$ significance level.

- H3a3 Transformational Leadership affects courtesy dimension by $\propto=0.05$ significance level.

- H3a4 Transformational Leadership affects civic virtue dimension by $\propto=0.05$ significance level.

- H3a5 Transformational Leadership affects altruism dimension by $\propto=0.05$ significance level.

Table 1: Profiles of the Resondents

\begin{tabular}{|c|c|c|}
\hline & Frequency & Percentage \\
\hline 25 vears and under & 24 & 8 \\
\hline $26-35$ & 149 & 49,7 \\
\hline $36-45$ & 95 & 31,7 \\
\hline 46- 55 & 25 & 8,3 \\
\hline 56 years and over & 7 & 2,3 \\
\hline Total & 300 & 100 \\
\hline Female & 172 & 57,3 \\
\hline Male & 128 & 42,7 \\
\hline Total & 300 & 100 \\
\hline Married & 103 & 34.3 \\
\hline Single & 197 & 65,7 \\
\hline Total & 300 & 100 \\
\hline Elementarv School & 3 & 1 \\
\hline Middle School & 9 & 3 \\
\hline High School & 16 & 5,3 \\
\hline College & 46 & 15,3 \\
\hline Bachelor degree/professional & 198 & 66 \\
\hline Master Degree/ PhD & 28 & 9,4 \\
\hline Total & 300 & 100 \\
\hline$<1$ vear & 20 & 6.7 \\
\hline $1-3$ years & 90 & 30 \\
\hline $4-6$ years & 103 & 34,3 \\
\hline $7-9$ years & 67 & 22,3 \\
\hline$>10$ years & 20 & 6,7 \\
\hline Total & 300 & 100 \\
\hline
\end{tabular}




\section{Analyses and Results}

The research result obtained after the findings were analyzed for the purposes of the research. Research hypotheses reliability and validity analysis in order to assess the accuracy of the scale used for multivariate scale in research before testing was performed. Four different scales were used for information sharing, teamworking, transformational leadership and OCB. A total of 54 variables were used for these four dimensions in the study.

\section{Table: 2 The relations between Knowledge Sharing and OCB.}

\begin{tabular}{|l|l|r|c|}
\hline Hypothesis & Relations & Conslusion \\
\hline H1a1 & $\begin{array}{l}\text { There is a relationship between conscientiousness dimension of OCB } \\
\text { responsibilities with Knowledge Sharing. }\end{array}$ & $* * *$ \\
\hline H1a2 & $\begin{array}{l}\text { There is a relationship between sportmanship dimension of OCB } \\
\text { responsibilities with Knowledge Sharing.. }\end{array}$ & $* * *$ \\
\hline H1a3 & $\begin{array}{l}\text { There is a relationship between courtesy dimension of OCB } \\
\text { responsibilities with Knowledge Sharing. }\end{array}$ & \multirow{2}{*}{ Partially } \\
S1a4 & $\begin{array}{l}\text { There is a relationship between civic virtue dimension of OCB } \\
\text { responsibilities with Knowledge Sharing. }\end{array}$ &, 001 \\
\hline H1a5 & $\begin{array}{l}\text { There is a relationship between altruism dimension of OCB } \\
\text { responsibilities with Knowledge Sharing. }\end{array}$ &, \\
\hline
\end{tabular}

Table: 3 The relations between Teamworking and OCB.

\begin{tabular}{|l|l|r|c|}
\hline Hypothesis & Relations & Conslusion \\
\hline H2a1 & $\begin{array}{l}\text { There is a relationship between conscientiousness dimension of OCB } \\
\text { responsibilities with teamworking. }\end{array}$ & $* * *$ \\
\hline H2a2 & $\begin{array}{l}\text { There is a relationship between sportmanship dimension of OCB } \\
\text { responsibilities with teamworking. }\end{array}$ &, 407 \\
\hline H2a3 & $\begin{array}{l}\text { There is a relationship between courtesy dimension of OCB responsibilities } \\
\text { with teamworking. }\end{array}$ & \multirow{2}{*}{ Partially } \\
Supported \\
H2a4 & $\begin{array}{l}\text { There is a relationship between civic virtue dimension of OCB } \\
\text { responsibilities with teamworking. }\end{array}$ & \multirow{2}{*}{, 003} & \\
\hline H2a5 & $\begin{array}{l}\text { There is a relationship between altruism dimension of OCB responsibilities } \\
\text { with teamworking. }\end{array}$ & \\
\hline
\end{tabular}

Table: 4 The relations between Transformational Leadership and OCB.

\begin{tabular}{|c|c|c|c|}
\hline Hypothesis & Relations & $\mathbf{P}$ & Conslusion \\
\hline H3a1 & $\begin{array}{l}\text { There is a relationship between conscientiousness dimension of OCB } \\
\text { responsibilities with Transformational Ledaership. }\end{array}$ & $* * *$ & \multirow{5}{*}{ Supported } \\
\hline H3a2 & $\begin{array}{l}\text { There is a relationship between sportmanship dimension of OCB } \\
\text { responsibilities Transformational Ledaership. }\end{array}$ & ,003 & \\
\hline H3a3 & $\begin{array}{l}\text { There is a relationship between courtesy dimension of OCB responsibilities } \\
\text { with Transformational Ledaership. }\end{array}$ & ,002 & \\
\hline $\mathrm{H} 3 \mathrm{a} 4$ & $\begin{array}{l}\text { There is a relationship between civic virtue dimension of OCB } \\
\text { responsibilities with Transformational Ledaership. }\end{array}$ & $* * *$ & \\
\hline H3a5 & $\begin{array}{l}\text { There is a relationship between altruism dimension of OCB responsibilities } \\
\text { with Transformational Ledaership. }\end{array}$ & ,003 & \\
\hline
\end{tabular}




\section{CONCLUSION}

In the scope of this study the effect of knowledge sharing, teamworking, transformational leadership on OCB was investigated. Considering of the strategic management, this study will be useful for the purpose of functioning effectively in organizations with their employees. In this context data was obtained from those 300 questionnaires in an educational institute that operates throughout Turkey. After the data is encoded using SPSS 17.0 and AMOS 18.0 tested. According to the hypothesis test hypothesis was accepted at the 0.05 significance level. According to the hypothesis test, the three main hypothesis of the research, due to the refusal of some sub-hypothesis was partially accepted. Knowledge sharing influences except civic virtue all other OCB dimensions. Teamworking influences except courtesy and conscientiousness all other dimensions of OCB. Transformational leadership influences all dimensions of OCB. As shown in our study, information sharing is a positive influence on organizational citizenship behavior. Employees with whom the necessary knowledge shared exhibit more OCB in the workplaces. With more knowledge employees become more empowered. In contrast to the hierarchical structure formed working groups (teams) within can create a vision for themselves and their OCB has been shown to increase with a lot size of workers to move freely in the framework of this vision. With this climate created by leaders in working environment, institutions can provide more benefits, show smooth and disinterested activities, own work, move efficiently, bring the institution to highest level. So these such organizations give the chance to work with employees who can help each other. The style of the leadership effects to the behaviors of employee in organizations. With transformational leadership style can a leader create a positive perceived climate for employees. In this climate employees show OCBs in organizations which effects the performance positively. In order to achieve an efficient and effective organization; management must create a climate within the knowledge sharing, team working and the effective leadership styles can be easily implemented to achieve organizational citizenship behaviors from their employees. In the future, the strategic advantage of an organization can be achieved by having a climate within the employees can act voluntarily as a citizen of their organization. 


\section{REFERENCES:}

Argote, L., Ingram, P., Levine, J.M., and Moreland, R.L. (2000). "Knowledge transfer in organizations: learning from the experience of others," Organizational Behavior and Human Decision Processes, (82:1), 18.

Bass, B. M., Waldman, D. A., Avolio, B. J., \& Bebb, M. (1987). “Transformational leadership and the falling dominoes effect”. Group and Organization Studies, 12, 73-78.

Beck, Ulrich (1992): “Risk Society: Towards a New Modernity” (Sage, London)

Bell, Daniel (1976): “The Coming of Post-Industrial Society: a Venture in Social Forecasting” (Basic Books, New York)

Bock, G.W., Shin, K.S., Suh, A., and Hu, A. (2010). "The factors affecting success of knowledge-based systems at the organizational level,” Journal of Computer Knowledge Systems (50:2), 95-105.

Bock, G.W., Zmud, R.W., Kim, Y.G., and Lee, J.N. (2005). “Behavioral intention formation in knowledge sharing: Examining the roles of extrinsic motivators, social-psychological forces, and organizational climate,” MIS Quarterly (29:1), 87-111.

Bolat, Tamer - Seymen, Oya Aytemiz (2003). "Örgütlerde İş Etiğinin Yerleş-tirilmesinde Dönüşümcü Liderlik Tarzının Etkileri Üzerine Bir Değerlendirme”, Balıkesir Üniversitesi Sosyal Bilimler Dergisi, 6(9), 59-85.

Bolino, M.C., W.H. Turnley and J.M. Bloodgood, (2002). "Citizenship behavior and the creation of social capital in organizations”. Academy of Management Review, 27: 505-522.

Chu C.I., Lee M. S., Hsu, H.M. (2006). The impact of social support and job stress on public health nugrses organizational citizenship behaviors. Public Health Nursing, Vol.23, No.6, 496-505.

Collins, J.D. and M.A. Hitt, (2006). "Leveraging tacit knowledge in alliances: The importance of using relational capabilities to build and leverage relational capital”. Journal of Engineering and Technology Management, 23: 147-167.

Demirel Y., Seçkin Z. and Özçınar M. F. (2011). "Interactions Between Knowledge Sharing and Organizational Citizenship Behavior”, Chinese Business Review, ISSN 1537-1506, 1(10), No. 11, 1061-1070.

Druskat VU, Wolf SB 1999. Effects of timing of developmental peer appraisals in self-managing work groups. Journal of Applied Psychology, 2: 78-94.

Effective Teamwork A Best Practice Guide for the Construction Industry www.constructingexcellence.org.uk .

Fang, Y., Jiang, G.L.F., Makino, S., and Beamish, P.W.(2010) “Multinational firm knowledge, use of expatriates, and foreign subsidiary performance,” Journal of Management Studies (47:1), 27-54.

Feather, N. T., Rauter, K. (2005). Journal Of Occupational And Organizational Psychology, 77, 81-94.

Fey, C.F., and Furu, P.(2008) "Top management incentivecompensation and knowledge sharing in multinational corporation,” Strategic Management Journal (29:12), 1301-1323.

Islam T., Anwar F., Khan S. U. R., Rasli A., Norulkamar U. Ahmad U. and Ishfaq A. (2012) "Investigating the Mediating Role of Organizational Citizenship Behavior Between Organizational Learning Culture and Knowledge Sharing”, World Applied Sciences Journal 19 (6): 795-799.

Ipe, M. (2003). Knowledge sharing in organizations: A conceptual framework. HRM Development Review, 2(4), 337-359.

Kankanhalli, A., Tan, B.C.Y., and Wei, K.K. (2005). “Contributing knowledge to electronic knowledge repositories: An empirical investigation,” MIS Quarterly (29:1), 113-143.

Kelchner, L. (2013). "Strengths and weaknesses of cross-functional teams”. Retrieved from: http://smallbusiness.chron.com/strengths-weaknesses-cross-functional-teams-24653.html. 
Journal of Global Strategic Management | V. 9 | N. 1 | 2015-June | isma.info | 75-86 | DOI: 10.20460/JGSM.2015915630

Lam, A., and Lambermont-Ford, J.P. (2010). "Knowledge sharing in organizational contexts: A motivationbased perspective,” Journal of Knowledge Management, (14:1), 51-66.

Mackenzie, S.B., Podsakoff, P. M., \& Fetter, R. (1993). The Impact of OCB on Evaluations of Sales Performance. Journal of Marketing, 57, 70-80.

Mackenzie, S. B., Podsakoff, P.M., \& Paine, J.E. (1998). Effects of OCB and Productivity on Evaluations of Performance at Different Hierarchical Levels in Sales Organizations. Journal of the Academy of Marketing Science, 27, 396-410.

Nadler, David A, and Michael L Tushman. 1982. "Managing Organizations Readings and Cases Frameworks for Organizational Behavior A Model for Diagnosing." In Managing Organizations: Readings and Cases, edited by David A Nadler, Michael L Tushman, and Nina G Hatvany. Little, Brown.

O’ Connor JF 1972. Leadership and organizational performance: A study of large corporations. American Sociological Review, 4: 117 - 130.

Organ, D. W. (1988). “Organizational Citizenship behavior: The good soldier syndrome”. Lexington, MA: Lexington Books.

Paillé Pascal (2011), Stressful Work, Citizenship Behaviour and Intention to Leave the Organization in a High Turnover Environment: Examining the Mediating Role of Job Satisfaction, Journal of Management Research, 2011, Vol. 3, No. 1: E1

Podsakoff, P.M. Mackenzei, S.B. (1995). An Examşniation of subsitutes for Leadership within alevels of analysis framework. Leadership Quarterly, 6, 289-328.

Podsakoof, P. M., Mackenzie, S.B., Paine, J. B., Bachrach, D. G. (2000). OCB: A Critical Review of the Theoretical and Emprical Literature and Suggestions for Future Research. Journal of Management, 26(3), 513-563.

Rukanc1, F., Hakan A. (2004), "Bilgi Toplumu ve Toplumun Bilgilenmesine Kütüphanelerin

Rolü”,Kütüphaneciliğin Destanı Uluslararası Sempozyumu Bildiriler,

http://acikarsiv.ankara.edu.tr/fulltext/165.htm,

Ryu S., Ho S.H., and Han I. (2003). “Knowledge sharing behavior of physicians in hospitals,” Expert Systems with Applications (25), 113-122.

Scarnati, J. T. (2001). “On becoming a team player”. Team Performance Management: An International Journal, 7(1/2), 5-10.

Schappe, S.P. (1998). The Influence Of Job Satisfaction, Organizational Commitment And Fairness Perceptions On Ocb. Journal Of Psychology, 132(3), 277-290.

Selvi Ö.(2012). "Bilgi Toplumu, Bilgi Yönetimi Ve Halkla İlişkiler”,Gümüşhane University E Journal Of Faculty Of Communication , 2,191-214.

Shang, S.S.C., Lin, S.F., and Wu, Y.L. (2009). "Service innovation through dynamic knowledge management,” Industrial Management \& Data Systems (109:3), 322-337.

Skogerbø, Eli \& Syvertsen, Trine (2004). “Towards An Knowledge Society? The Value Of Media Production And Consumption”. Javnost - The Public. ISSN 1318-3222. 11(1),45- 60

Sohmen V. S.(2013).” Leadership and Teamwork: Two Sides of the Same Coin”, Journal of IT and Economic Development 4(2), 1-18.

Somech A.; Zahavy D. (2004). Exploring Organizational Citizenship Behavior From An Organizational Perpective. Journal of Occupational and Organizational Psychology, 77, 281-298.

Tarricone P, Luca J.(2002).” Successful teamwork: A case study” HERDSA Conference 640-646.

Van Dyne, L., Graham, J., Dinesch, R. (1994). Organizational Citizenship Behavior: Construct Redefinition, Measurement, and Validation. Academy of Management Journal, Vol. 37, No. 4, 765-802. 
Van Dyne, L., Cummings, L. L. (1990). Extra role behaviors: In pursuit of construct and definitional clarity, Paper presented at the annual meeting of the Academy of Management, San Francisco.

Wayne S.J., Green, S.A. (1993). The Effects of Leader-member exchange on employee citizenship and impression management behavior. Human Relations, 46, 1431-1440.

Williams, L. J., Anderson, S.E. (1991). Job Satisfaction And Organizational Commitment As Predictors Of Organizational Citizenship And In-Role Behaviors. Journal Of Management, 17, 601-617

Zellars, K.L., Tepper, B., Dufy, M.K. (2002). Abusive supervision, and subordinates' organizational citizenship behaviors. Journal of Applied Pschology, Vol. 87, No. 6, 1068- 1076.

Whetten, D. A. \& Cameron, K. S. (2011). “Developing management skills. Upper Saddle River”, NJ: Prentice Hall/Pearson.

Yıldırım U., Öner Ş., (2004). "Bilgi Toplumu Sürecinde Yerel Yönetimlerde Eğitim-Bilişim Teknolojisinden Yararlanma : Türkiye'de E-Belediye Uygulamaları”, The Turkish Online Journal of Educational Technology - TOJET, 1303-6521 3(1) Article 8,49-60. 